\title{
Erratum to: Pure Laparoscopic Liver Resection for Large Malignant Tumors: Does Size Matter?
}

Vishal G. Shelat, FRCS, FICS ${ }^{1,2}$, Federica Cipriani, MD ${ }^{1}$, Tiago Basseres, MD ${ }^{1}$, Thomas H. Armstrong, FRCS, PhD $^{1}$, Arjun S. Takhar, FRCS, PhD ${ }^{1}$, Neil W. Pearce, FRCS, PhD ${ }^{1}$, and Mohammad Abu Hilal, MD, FRCS, PhD, DocEurp ${ }^{1}$

${ }^{1}$ University Hospital Southampton NHS Foundation Trust, Southampton, UK; ${ }^{2}$ Tan Tock Seng Hospital, Singapore, Singapore

\section{ERRATUM TO: ANN SURG ONCOL}

\section{DOI 10.1245/S10434-014-4107-6}

The correct family name of Mohammad Abu Hilal is as shown in this erratum.

The online version of the original article can be found under doi:10. 1245/s10434-014-4107-6.

(C) Society of Surgical Oncology 2014

Published Online: 8 November 2014

M. Abu Hilal, MD, FRCS, PhD, DocEurp

e-mail: abuhila19@gmail.com 